\title{
Evolusi Institusi Pendidikan Islam Klasik Evolution of Classical Islamic Education Institutions
}

\author{
Muhammad Yunus Ibrahim \\ IAIN Langsa \\ yunusibrahim1959@gmail.com
}

\begin{abstract}
This article aims to export the History of Islamic Education which has lasted approximately 14 centuries ago, that is since the prophet Muhammad was sent to be an apostle. Initially, education took place simply, with the mosque as the centre of the learning process, the Koran and Hadith as the main curriculum of the Prophet himself acted as a teacher in the education process, but after the Prophet's death, Islam continued to develop to the end of the Arabian peninsula. Islamic educational institutions are very important in achieving the success of the education process because the institution functions as a mediator in regulating the course of the educational process. Nowadays it seems that education cannot be called if there is no institution. Because education plays a central role in Islam. Science becomes the backbone of Islamic teachings. More than 800 verses of the Qur'an mention, allude or discuss the importance of science. Just a comparison, only 90 Quranic verses discuss fiqh or Islamic jurisprudence. Islamic education is very closely related to educational institutions because Islamic education has an institution that helps. Islamic educational institutions are a place or place where the process of Islamic education takes place simultaneously with the process of civilization, and it starts from the family environment.
\end{abstract}

Keywords: Evolution, Educational Institution, Classic

\begin{abstract}
Abstrak
Artikel ini bertujuan mengeksporasi Sejarah Pendidikan Islam telah berlangsung kurang lebih 14 abad yang telah lalu, yakni sejak nabi Muhammad diutus menjadi rasul. Pada awalnya pendidikan berlangsung secara sederhana, dengan masjid sebagai pusat proses pembelajaran, Alquran dan Hadis sebagai kurikulum utama Rasulullah sendiri berperan sebagai guru dalam proses pendidikan tersebut, tetapi setelah Rasulullah wafat Islam terus berkembang sampai ke ujung jazirah Arab. Lembaga pendidikan Islam merupakan hal yang sangat penting dalam mencapai keberhasilan proses pendidikan, karena lembaga berfungsi sebagai mediator dalam mengatur jalannya proses pendidikan. Dewasa ini tampaknya tidak bisa disebut pendidikan apabila tidak ada lembaganya. Karena pendidikan memainkan peran sentral dalam Islam. Ilmu menjadi tulang punggung (backbone) ajaran Islam. Lebih dari 800 ayat Alquran menyebut, menyinggung atau membahas tentang pentingnya keilmuan. Sekedar perbandingan, hanya 90 ayat Alquran yang membahas tentang fiqh atau ilmu hukum Islam. Pendidikan Islam, sangatlah erat hubungannya dengan lembaga-lembaga pendidikan karena suatu pendidikan Islam meliki lembaga yang membantu. Lembaga pendidikan Islam adalah wadah atau tempat berlangsungnya proses pendidikan Islam yang bersamaan dengan proses pembudayaan, dan itu dimulai dari lingkungan keluarga.
\end{abstract}

Kata Kunci: Evolusi, Istitusi Pendidikan, Klasik 


\section{A. Pendahuluan}

Kelahiran lembaga pendidikan Islam tumbuh seiring dengan kelahiran dan pertumbuhan penyebaran Islam itu sendiri, yang sangat terkait dengan proses dakwah Islamiyah, sehingga bentuknya belum Nampak secara formal (Mukti, 2008). Proses pendidikan Islam awal lebih banyak dilaksanakan dirumah-rumah para sahabat yang dikenal dengan Dar al Arqom. Kemudian ketika masyarakat muslim sudah terbentuk, maka pendidikan Islam dilaksanakan di masjid-masjid. Kedua macam pendidikan ini memakai metode halaqah atau lingkaran belajar (Syukur, 2015).

Dalam perkembangan pendidikan masa selanjutnya banyak lembagalembaga pendidikan Islam berkembang pesat, seperti munculnya kuttab, madrasah, ribath, zawiyah, dan khanaqoh. Kuttab ini berkembang di masa Bani Umaiyah sedangkan madrasah adalah Dinasti Abbasiyah. Bagaimana dengan ribath, zawiyah, dan khanaqah (Zuhairini, 2010). Lembaga pendidikan ribath, zawiyah, dan khanaqah ini adalah lembaga pendidikan yang berkembang di dunia para sufi, lembaga pendidikan ribath, zawiyah, dan khanaqah ini merupakan suatu lembaga yang berperan sebagai penampung para pengikut sufi dan sekaligus sebagai tempat untuk memperdalam ilmu pengetahuan mereka tentang bagaimana cara beribadah mendekatkan diri kepada Allah denangan berbagai macam kegiatan dan latihan (Emroni, 2015).

Dalam bahasa Inggris lembaga disebut institute (dalam pengertian fisik), yaitu sarana atau organisasi untuk mencapai tujuan tertentu, dan lembaga dalam pengertian non-fiksi atau abstrak disebut institution yaitu suatu system norma untuk memenuhi kebutuhan. Lembaga dalam pengertian fisik disebut juga dengan bangunan, dan lembaga dalam pengertian non-fisik disebut dengan pranata (Ramayulis, 2002).

Secara terminology menurut Hasan Langgulung, Lembaga pendidikan adalah suatu system peraturan yang bersifat mujarrad, suatu konsepsi yang terdiri dari kode-kode, norma-norma, ideologi-ideologi dan sebagainya, baik tertulis maupun tidak tertulis, termasuk perlengkapan material dan organisasi simbolik: kelompok manusia yang terdiri dari individu-individu 
yang dibentuk dengan sengaja atau tidak, untuk mencapai tujuan tertentu dan tempat-tempat kelompok itu melaksanakan peraturan-peraturan tersebut adalah: masjid, sekolah, kuttab dan sebagainya (Langgulung, 1988).

Lembaga pendidikan Islam dapat pula diartikan suatu wadah atau tempat berlangsungnya proses pendidikan Islam. Dari devinisi diatas dapat disimpulkan bahwa lembaga pendidikan itu mengandung pengertian konkret berupa sarana pra sarana dan juga pengertian yang abstrak, dengan adanya norma-norma dan peraturan-peraturan tertentu, serta penanggung jawab pendidikan itu sendiri (Ramayulis, 2002).

Dalam dunia pendidikan Islam juga mengalami sejarah, dalam perjalanan sejarah pendidikan Islam salah satunya dikenal lembaga pendidikan ribath, zawiyah dan khanaqoh. Lembaga pendidikan ini bermula dari tempat-tempat kumpul para tentara Islam, di mana ditempat itu sering terjadi percakapan strategi, agama dan pembahasan masalah jihad, yang kemudian dalam perkembangan sejarahnya menjadi suatu lembaga pendidikan tersendiri, dimana lembaga pendidikan bukan membahas masalah jihad dalam peperangan, tapi jihad fi nafsi, yaitu jihad memerangi hawa nafsu. Dalam makalah ini penulis mencoba menghadirkan urgensi dan keberadaan dari lembaga-lembaga pendidikan ribat, zawiyah dan khanaqoh dalam pendidikan Islam (Ramayulis, 2002).

\section{B. Hasil dan Pembahasan}

\section{Lembaga Pendidikan Islam}

\section{a. Ribath}

Al-Ribath secara harfiah berarti ikatan yang mudah dibuka. Sedangkan dalam arti yang umum, al-Ribath adalah tempat untuk melakukan latihan, bimbingan dan pengajaran bagi calon sufi (Yatim, 2010). Ribat adalah tempat kegiatan kaum sufi yang ingin menjauhkan diri dari kehidupan duniawi, dan mengonsentrasikan diri untuk semata - mata ibadah. Juga memberikan perhatian terhadap kegiatan keilmuan yang dipimpin oleh seorang syeikh yang terkenal dengan ilmu dan kesalehannya (Engku dan Zubaidah, 2014). 
Kata Ribath dalam bahasa Arab memiliki beberapa arti (1) Sesuatu yang dibuat untuk mengikat (tali dan sebagainya), membalut, (2) Sekawanan kuda, rombongan (pasukan) berkuda (3) Tangsi, markas tentara (4) Tempat diwakafkan untuk fakir miskin (5) Hati. Dalam bahasa Indonesia kata Ribat mengandung arti gedung atau tempat melakukan pelatihan ibadah dan kewajiban lain. Dalam bahasa Spanyol kata Ribat berasal dari kata Ribato yang berarti "Serangan balik yang berdasarkan metode perang klasik" (Taswir, nd).

Hasan As'ari menjelaskan bahwa ribath semula adalah barak-barak tentara muslim yang berada di garis depan pertempuran. Ribath diposisikan di perbatasan daerah yang masih dikuasai musuh atau yang sedang dalam proses penaklukan. Seiring dengan perjalanan waktu dan kondisi politik, maka penghuni ribath mengalihkan kecenderungan hidup dari pola perang fisik melawan musuh ke pola perang melawan diri dan jiwa dengan praktik sufi. Dijelaskan dalam Ensiklopedi Islam bahwa Syaykh 'Abd al-Qadir alJailani menggunakan model ribath untuk tempat tinggal bersama keluarga dan tempat belajar muridnya dibanding model yang lain (Sahri, 2011).

Sebagian tokoh mengatakan bahwa istilah Ribath diambil dari firman Allah swt. dalam surat al-Anfal ayat 60:

Artinya: dan siapkanlah untuk menghadapi mereka kekuatan apa saja yang kamu sanggupi dan dari kuda-kuda yang ditambat untuk berperang (yang dengan persiapan itu) kamu menggentarkan musuh Allah dan musuhmu dan orang orang selain mereka yang kamu tidak mengetahuinya; sedang Allah mengetahuinya. apa saja yang kamu nafkahkan pada jalan Allah niscaya akan dibalasi dengan cukup kepadamu dan kamu tidak akan dianiaya (dirugikan).

Ribath adalah sebuah istilah yang menunjukkan tempat berkumpulnya para sufi dan ahli tarekat guna melaksanakan latihan-latihan spiritual. Menurut Maqrizi, Ribath adalah rumah para sufi, setiap kelompok (kaum) mempunyai rumah dan ribath adalah rumah para sufi. Dalam hal ini mereka mirip dengan ahli al-Suffah (sekelompok sahabat yang mendiami emperan masjid Nabi di Madinah). Penghuni ribath adalah orang yang mempunyai 
ikatan (murabith) dengan maksud, tujuan serta keadaan yang sama. Ribath dibangun untuk (mempunyai) maksud tujuan ini.

\section{b. Zawiyah}

Az-Zawiyah secara harfiyah berarti sayap atau samping. sedangkan dalam arti yang umum, az-zawiyah adalah tempat yang berada dibagian pinggir masjid yang digunakan untuk melakukan bimbingan wirid, dan dzikir untuk mendapatkan kupasan spiritual. Dengan demikian, az-zawiyah dan alribath fungsinya sama, namun dari segi organisasinya al-ribath lebih khusus dari pada az-zawiyah (Nata, 2011). Adapun Zawiyah menyerupai khanaqah dari segi tujuan, Akan tetapi zawiyah ini lebih kecil dari pada khanaqah, dan dibangun untuk orang-orang tasawuf yang faqir supaya mereka dapat belajar dan beribadat. contohnya salah seorang raja dari al-Mamalik membangun sebuah Zawiyah al-Jumairah. Dan ditempatkan didalamnya beberapa orang sufi yang fakir. Kadang-kadang pula Zawiyah itu didirikan untuk seorang syaikh yang termasyhur yang bertugas untuk menyiarkan ilmu pengetahuan dan mengasingkan diri untuk beribadat. Pada umumnya Zawiyah itu dikenal dengan nama seorang Syaikh yang terkenal dengan banyak ilmunya dan taqwanya.

Di zawiyah ini, fiqh seperti halnya ilmu-lmu yang lain, sesuai dengan bidang syaikhnya, merupakan bagian dari kegiatan pewarisan ilmu pengetahuan. Belakangan, terutama setelah munculnya tarekat-tarekat sufi, zawiyah dibangun sebagai institusi yang berdiri sendiri. Aboebakar Atjeh (1992) menekankan fungsi pendidikan yang berlangsung di zawiyah dengan mengatakan: Zawiyah itu merupakan satu ruang tempat mendidik caloncalon sufi, tempat mereka melakukan latihan-latihan tarekatnya, diperlengkapi dengan mihrab untuk mengerjakan sembahyang berjamaah, tempat mereka membaca al-Qur'an dan mempelajari ilmu-ilmu yang lain, sehingga zawiyah itu merupakan sebuah asrama dan madrasah. 
Suatu penelitian yang mencakup Mesir menjelang penaklukan Turki Utsmani menunjukkan adanya dua jenis zawiyah:

1) Zawiyah tradisional yang mempunyai hubungan erat dengan penguasa (Mamluk)

2) Zawiyah yang lebih independen. Jenis kedua ini biasanya sekaligus menjalankan fungsi masjid dan ribâth: menyediakan fasilitas beribadah, sekaligus perlindungan dan makanan bagi orang-orang miskin. Independensi ini dapat dilihat dalam contoh Syaikh Ibn Qiwam yang selalu menolak tawaran wakaf untuk zawiyah-nya yang dia bangun dengan biayai sendiri (Asari, 1994).

Sementara di Kairo misalnya, sebelum dan pada masa Mamluk sekurang-kurangnya terjadi lima madrasah yang didirikan perempuan. Madrasah tersebut bisa berbentuk pondokan Zawiyah, yaitu: Pertama, Madrasah Asyuriyyah, istri seorang Amir, dilingkungan Zuwayla, Kairo. Kedua, Madrasah al-Qutbiyyah yang didirikan oleh Ismet al-Din, putri Sultan Ayubiyyah, al-Malik al-Adil, dan saudara perempuan al-Malik al-Afdhal Qutb al-Din Ahmad. Oleh karena itu madrasah yang didirikan pada akhir abad 13 M ini juga dikenal sebagai Madrasah Ismad al-Din.

Ketiga, Madarasah Hijaziyyah didirikan dan diwakafkan oleh putri Sultan al-Nasir Muhammad, yang menikah dengan Amir Mamluk bernama Bahtimur al-Hijazi, dan nama yang terakhir disebut kemudian diabadikan sebagai nama madrasah tersebut. Selain madrasah, sang putri ini juga membangun kubah yang pada gilirannya menjadi tempat peristirahatan akhirnya ketika wafat. Madrasah ini terkenal dengan spesialisasi dalam bidang fikih Syafi'i dan Maliki. Keempat, Madrasah yang didirikan Barakat, ibu Sultan Asyraf Saban (1369-1370), yang terkenal khususnya dalam bidang fikih madzhab Syafi'i dan Hanafi. Kelima, Madrasah Ummu Khawan Yang didirikan Fatimah binti Qanibay al-Umari al-Nasiri, Istri tentara Mamluk bernama Taghri Birdi al-Muadzdzi (Azra, 1999). 


\section{c. Khanqah}

Merupakan suatu lembaga pengajaran berasrama bagi kaum sufi yang muncul pertama kali di Iran (Persia) pada akhir abad ke-10 bersamaan dengan adanya formalisasi aktivitas sufistik. Khanqah berasal dari bahasa Persi Okhaniqah yang dalam bentuk jamaknya adalah Khanqaha. Ada juga yang berpendapat bahwa khanaqah itu berasal dari bahasa arab Khanqah yang dalam bentuk jamaknya adalah khawanik semuanya itu bermakna ruang atau rumah. Namun istilah Khanqah ini baru mendapat perhatian dari para sejarawan.

Dalam perkembangannya istilah ini digunakan Muhammad Ibnu Karram, seorang pelajar hadis dan penyebar paham asketik di Iran Selatan dan Iran Timur. Dia berhasil meraih pengikut dari masyarakat kelas bawah transoxania Afganistan dan Iran Timur, Yang mengajarkan sebuah jalan hidup menuju taqwa Allah. Guru sufi yang mengikuti tindakannya ialah Syaikh Abu Ishaq Ibrahim al-Kazaruni, dia menampung sejumlah besar Pengikut sufi di rumahnya di Iran Barat. Ia juga membangun 65 Khanaqah Iran Selatan sebagai pusat pengajaran, pusat misionari dan tempat mendistribusikan shodaqah pada fakir miskin.

Keluarga dekatnya yang bernama Abu Sa'id Ibnu Abu al-Khoir yang lahir dan meninggal di Nishapur adalah guru besar sufi yang pertama kali menyusun aturan-aturan peribadatan dan sebuah kitab hukum perilaku dan mengatur kehidupan komunal khanaqah. Sekitar akhir abad ke-11 selain berfungsi missionari, tetapi juga digunakan untuk makam guru-guru besar sufi dan akhirnya menjadi tempat peziarah mukim awam. Aturan- aturan tersebut antara lain ialah:

a) Ahli Khanqah harus memperhatikankebersihan baik kebersihan fisik maupun kebersihan spiritual. Seluruh tempat tinggal tempat ibadah, harus selalu dalam keadaan suci. Sangat dianjurkan mereka agar memelihara wudlu secara berkesinambungan.

b) Ahli Khanqah tidak dibenarkan menghabiskan waktu dengan berbincang-bincang, lebih-lebih di tempat khanqah atau tempat suci lainnya. 
c) Ahli Khanqah harus melaksanakn shalat lima waktu secara berjama'ah pada awal waktu.

d) Ahli Khanqah harus melaksanakan qiyam a1-lai1 (shalat malam) yang panjang untuk lebih mendekatkan diri kepada Allah.

e) Ahli Khanqah harus menggunakan waktu setelah shalat subuh untuk memanjatkan do'a dan memohon ampun.

f) Ketika menjelang pagi harus melajutkan kegiatannya itu dengan membaca Alqur'an sebanyak mungkin biasanya sampai siang.

g) Pada waktu siangnya juga harus mengurusi fungsi sosial seperti mengurusi orang-orang fakir yang datang ke khanqah demi untuk mendapatkan sesuap nasi.

h) Mengembangkan tradisi makan bersama, demi mempertebal rasa persaudaraan dan kebersamaan dalam menikmati rahmat Tuhan.

i) Kebersamaan ini betul-betul mereka tanamkan, seperti ahli khanqah tidak boleh meninggalkan khanqah tanpa memberi tahu pada salah seoranag yang hadir di sana.

j) Waktu shalat Isya' keseluruhannya harus dimanfaatkan untuk zikir dan wirid

\section{Kurikulum Pendidikan}

Pada masa klasik, pakar pendidikan Islam menggunakan kata almaddah untuk pengertian kurikulum. Karena pada masa itu kurikulum lebih identik dengan serangkaian mata pelajaran yang harus diberikan pada murid dalam tingkat tertentu (Nata, 2012).

a) Kurikulum Pendidikan Islam Sebelum Berdirinya Madrasah. Kurikulum Pendidikan Rendah. Terdapat kesukaran ketika membatasi mata pelajaran yang membentuk kurikulum untuk semua tingkat pendidikan yang bermacam-macam. Pertama, karena tidak adanya kurikulum yang terbatas, baik untuk tingkat rendah maupun tingkat penghabisan, kecuali Alquran yang terdapat pada seluruh kurikulum. Kecuali, kesukaran menbedakan di antara fase-fase pendidikan dan lamanya belajar karena 
tidak ada masa tertentu yang mengikat murid-murid untuk belajar pada setiap lembaga pendidikan.

b) Kurikulum Pendidikan Tinggi, Menurut rahman, pendidikan jenis ini disebut pendidikan orang dewasa karena diberikan kepada orang banyak yang tujuan utamanya adalah untuk mengajarkan mereka mengenai Alquran dan agama. Kurikulum pendidikan tingkat ini dibagi kepada dua jurusan, jurusan ilmu-ilmu agama dan jurusan ilmu pengetahuan.

c) Kurikulum Setelah Berdirinya Madrasah

Berdirinya madrasah, pada satu sisi, merupakan sumbangan islam bagi peradaban sesudahnya, tapi pada sisi lain membawa dampak yang buruk bagi dunia pendidikan setelah hemegoni negara terlalu kuat terhadap madrasah ini.

Pendidikan Islam adalah rangkaian usaha membimbing, mengarahkan potensi hidup manusia yang berupa kemampuan-kemampuan dasar dan kemampuan belajar, sesuai dengan nilai-nilai Islam, sehingga terjadilah perubahan pribadinya sebagai makhluk individual, sosial serta dalam hubungannya dengan alam sekitar dimana ia hidup. Untuk mencapai pada pengertian pendidikan tersebut tentunya seorang pendidik memerlukan metode-metode yang tepat dalam pelaksanaan pendidikan. Adapun metode yang digunakan dalam pendidikan klasik antara lain metode ceramah, dialog, diskusi/tanya jawab, metode perumpamaan, metode kisah, metode pembiasaan, dan metode hafalan.

\section{Metode Pendidikan Sufistik Masa Klasik}

1. Metode Graduasi (Al-Tadarruj); Metode graduasi atau penahapan merupakan metode Alquran dalam membina masyarakat, baik dalam melenyapkan kepercayaan dan tradisi jahiliyah maupun yang lain. Demikian pula dalam menanamkan aqidah, Alquran juga menggunakan metode graduasi ini. Oleh sebab Alquran diturunkan kepada Rasul secara berangsur-angsur (bertahap), maka tidak heran juga ketika Nabi menerapkan konsep tersebut dalam penyampaian pendidikannya. 
2. Metode Levelisasi; Penyampaian materi pelajaran yang dilakukan Nabi Muhammad sering berbeda antara orang satu dengan orang yang lain. Hal ini beliau lakukan, karena beliau sangat memperhatikan level-level atau peringkat dan kemampuan kecerdasan intelektual seseorang dalam menangkap sebuah pelajaran. Demikian dilakukan dengan tujuan agar materi yang disampaikan beliau benar-benar bias diterima oleh peserta didik. Terkadang Rasulullah berbicara tidak hanya memperhatikan tingkat kecerdasan seseorang saja, melainkan juga memperhatikan kecerdasan emosionalnya.

3. Metode Variasi (Al-Tanwi' Wa Al-Taghyir); Untuk menghindari kejenuhan atau kebosanan para peserta didik, Nabi Muhammad membuat variasi waktu dalam memberikan pelajaran kepada para sahabat. Tidak hanya bervariasi dalam hal waktu, beliau juga memberikan variasi-variasi dalam penyampaian materi pelajaran. Karena yang beliau ajarkan adalah wahyu dari Allah yang pada saat itu sedang dalam proses diturunkan. Oleh sebab materi yang dikirimkan lewat wahyu itu bervariasi, maka secara otomatis pendidikan yang diajarkan Rasulullah bervariasi. Menurut Prof. Dr. Muhammad 'Ajjal al Khatib, metode variasi ini, baik digunakan dalam materi pelajaran manapun (Ali, 1997).

4. Metode Keteladanan (Al-Uswah wa Al-Qudwah); Ketika Rasulullah Muhammad memberikan sebuah materi yang berkaitan pola perilaku atau tingkah laku yang berkaitan dengan aplikasi dalam kehidupan sehari-hari, sebelum beliau menyampaikan kepada peserta didik, terlebih dahulu beliau melakukannya dalam perbuatan sehari-hari. Dengan hal demikian, maka peserta didik akan lebih cepat memahami ajaran Rasulullah. Selain itu, di dalam (Qs. Al-Ahzab: 21) juga telah disebutkan bahwa:

Artinya: Sesungguhnya telah ada pada (diri) Rasulullah itu suri teladan yang baik bagimu (yaitu) bagi orang yang mengharap (rahmat) Allah dan (kedatangan) hari kiamat dan Dia banyak menyebut Allah. 
5. Metode Aplikatif (At-Tatbiqi Wa Al-'Amali); Apabila Rasulullah sudah memberikan teladan-teladan dalam ajaran-ajaran yang beliau sampaikan kepada peserta didik, maka pada gilirannya peserta didikpun langsung mempraktikan dan mengaplikasikan ajaran-ajaran itu dalam kehidupan sehari-hari. Pendidikan Nabi Muhammad tidak sekedar menyampaikan materi pelajaran saja, melainkan juga langsung diamalkan.

6. Metode Pengulangan (Al-Taqrir Wa Al-Muraja'ah); Metode pengulangan menjadi salah satu metode yang digunakan beliau, karena dianggap perlu dan penting untuk dilakukan khususnya dalam materi pelajaran yang penting-penting.

7. Metode Evaluasi (Al-Taqyim); Sebuah metode yang digunakan oleh Rasul dalam penyampaian materi pelarannya, dimana Beliau tidak hanya berhenti setelah sudah memberikan materi kepada peserta didik, akan tetapi beliau juga melakukan sebuah tindakan monitoring dan evaluating. Dalam hal ini, beliau mengawasi dan mengevaluasi mereka. Apabila terdapat kekeliruan, maka Beliau langsung mengoreksinya. Oleh karena kekeliruan tersebut bisa diketahui langsung oleh Beliau dan terkadang diketahui lewat laporan dari seseorang sahabat.

8. Metode Dialog (Al-Hiwar); Metode pendidikan Rasulullah selanjutnya adalah Al-Hiwar yaitu dialog, Tanya jawab. Dalam hal ini Rasul, berperan sebagai penanya dan pendialog. Sementara peserta didiknya yang diajak dialog. Dengan metode ini, Beliau membentuk peserta untuk melakukan perubahan yaitu dari tidak tahu menjadi mengetahui, kemudian dan memahami, dan yang selanjutnya sampai ke posisi meyakini. Metode ini banyak mewarnai system pendidikan Islam pada masa Rasulullah.

9. Metode Analogi (Al-Qiyas); Penerapan metode ini dalam pendidikan Rasul disini Beliau seringkali menyebutkan ungkapan-ungkapan dalam mengajarkan agama Islam kepada peserta didik.

10. Metode Cerita; Metode ini dikemas dengan cara bercerita. Untuk menanamkan ajaran-ajaran Islam kepada peserta didik, Rasul seringkali menuturkan kisah orang - orang terdahulu. 


\section{Kontribusi Pendidikan Sufistik Pada Masa Klasik}

Pemikiran Islam merupakan hasil pergumulan antara normatifitas dengan historisitas. Pemikiran keagamaan Islam (dari para pemikir muslim baik individu atau kelompok) merupakan hasil usaha intelektual muslim dalam mempertemukan wahyu (sebagai sumber ajaran Islam) dengan situasi dan kondisi tertentu atau perkembangan sejarah dalam kurun waktu tertentu. Dalam kajian yang lebih lanjut, telah dilakukan upaya bagaimana mengambil relevansi dan sumbangan serta kesinambungan intelektualisme masa lalu untuk dikaitkan dengan problem kaum muslim saat ini (Syukur, 2015). Dapat dikatakan bahwa pemikiran keagamaan Islam serta konsep yang terkait di dalamnya tidak bisa dilepaskan sama sekali dari perubahan sejarah yang mengitarinya (Abdullah, 1999).

Ungkapan demikian dapat dilihat dalam khasanah keilmuan Islam klasik, baik dalam bidang pemikiran Filsafat, Kalam, maupun Tasawuf. Dalam pemikiran Filsafat Islam, terdapat konsep penciptaan alam melalui emanasi. Konsep ini merupakan pengaruh teori emanasi Neoplatonisme dari Yunani yang mulai berkembang di dunia Islam. Dalam pemikiran Kalam, khususnya aliran Mu'tazilah, terdapat konsep tauhid (mengesakan Tuhan). Konsep ini merupakan upaya kaum Mu'tazilah untuk mengesakan Tuhan secara murni dan sekaligus menghilangkan pengaruh paham sifatiyah atau jismiyah. Tuhan tidak memiliki sifat, Ia hanya Esa dalam dzat dan af'alNya (Nasution, 1986).

Paham sifatiyah atau jismiyah merupakan pengaruh filsafat Yunani yang menganggap bahwa dalam diri Tuhan melekat sifat-sifat seperti manusia. Sedangkan dalam Tasawuf terdapat konsep mahabbah (mendekati Tuhan dengan cinta). Konsep yang dipelopori oleh Rabi'ah al-Adawiyah ini merupakan hasil pergumulan antara ajaran Islam tentang cinta kepada Tuhan dengan realitas masyarakat pada akhir abad ke-2, di mana pada saat itu perkembangan fiqh hanya mengutamakan hal-hal yang bersifat lahiriah (eksoteris) dan mengabaikan dimensi Islam yang batiniah (esoteris) (Simuh, 1997). 
Perlu dicatat bahwa perkembangan fiqh tidak lepas dari pengaruh dari pandangan rasional-filosofis. Implikasi dari uraian di atas adalah bahwa produk pemikiran Islam, baik dalam Filsafat, Kalam, maupun Tasawuf (dan Fiqh), akan selalu berkembang sesuai dengan perkembangan sejarah, sehingga memungkinkan adanya perbedaan-perbedaan antara produk pemikiran Islam pada masa lalu (klasik) dengan produk pemikiran Islam pada masa kini dan nanti (kontemporer). Tamim Anshary mengeleompokkan warisan Islam klasik kedalam tiga figur, yaitu ulama, filosof, dan sufi. Ketiganya merupakan agen penting dalam perkembangan peradaban dan keilmuan Islam (Anshary, 2015).

\section{Kesimpulan}

Ribath, Zawiyah dan Khanqah adalah merupakan suatu lembaga yang berperan sebagai penampung para pengikut sufi dan sekaligus sebagai tempat untuk memperdalam ilmu pengetahuan mereka tentang bagaimana cara beribadah mendekatkan diri kepada Allah dengan berbagai macam kegiatan dan latihan. Zawiyah, adalah lembaga sufi yang lebih khusus yang lebih kecil ruang lingkupnya, sehingga dalam lembaga ini tidak terdapat aturan-aturan sebagaiman yang ada dalam Khanqah. Lembaga ini didirikan oleh seorang Syaikh yang bertujuan untuk memperluas ajaran-ajaran tarekat tertentu. Khanaqah itu berasal dari bahasa arab, Khanqah yang dalam bentuk jamaknya adalah khawanik semuanya itu bermakna ruang atau rumah. Kebersamaan ini betul-betul mereka tanamkan, seperti ahli khanqah tidak boleh meninggalkan khanqah tanpa memberi tahu pada salah seoranag yang hadir di sana. Sistem pendidikan sufi, merupakan suatu sistem yang agak berbeda dengan sistem pendidikan yang lain, karena di dalam tasawuf sangat mementingkan aspek emosional.

\section{DAFTAR PUSTAKA}

Atjeh, Aboe Bakar, 1992, Pengantar Ilmu Tarekat, Solo: Ramadhani. Asari, Hasan, 1994, Menyingkap Zaman Keemasan Islam, Bandung: Mizan. 
Azra, Azyumardi, 1999, Membongkar Peranan Perempuan dalam Bidang Keilmuan, Jakarta: JPPR.

Abdullah, M. Amin, 1995, Falsafah Kalam di Era Postmodernisme, Yogyakarta: Pustaka Pelajar. tp,1997, Studi Agama: Antara Normatifitas dan Historisitas, Yogyakarta: Pustaka Pelajar.

Anshary, Tamim, 2015, Dari Puncak Bagdad: Sejarah Dunia Versi Islam, terj. Yuliani Liputo, Jakarta: Zaman.

Engku, Iskandar, dan Siti Zubaidah, 2014, Sejarah Pendidikan Islami, Bandung: PT. Remaja Rosdakarya.

Emroni, 2015, Kontribusi Lembaga Sufi Dalam Pendidikan Islam, Jurnal Taswir.

Fahmi, Asma Hasan, 1979, Mabaadiut Tarbiyatil Islaamiyah, Jakarta: Bulan Bintang.

Langgulung, Hasan, 1988, Pendidikan Islam Menghadapi Abad ke-21, Jakarata: Pustaka Al-Husna.

Muhammad, Suwarsono, 2015, Ekonomi Politik Peradaban Islam Klasik, Jakarta: Ombak.

Mukti, 2008, Pembaharuan Lembaga pendidikan di Mesir, Bandung: Cita Pustaka Media Perintis.

Nata, Abudin, 2011, Sejarah Pendidikan Islam, Jakarta: Kencana.

Nasution, Harun, 1986, Teologi Islam: Aliran-aliran Sejarah Analisa Perbandingan, cetakan V. Jakarta: UI Press.

Ramayulis, 2002, Ilmu Pendidikan Islam, Jakarta: Kalam Mulia.

Syukur, Fatah, 2015, Sejarah Peradaban Islam, Semarang: Pustaka Rizki Putra.

Syukur, Suparman, 2007, Epistemologi Islam Skolastik Pengarushnya pada Pemikiran Islam Modern, Yogyakarta: Pustaka Pelajar.

Simuh, 1997, Tasawuf dan Perkembangannya dalam Islam, Jakarta: Rajawali Pers.

Yatim, Badri, 2010, Sejarah Pendidikan Islam, Jakarta: Rajawali Pers. 
Yaqub Ali, Mustafa, 1997, Sejarah dan metode Dakwah Nabi, Jakarta: Pustaka Firdaus.

Zuhairini, 2010, Sejarah Pendidikan Islam, Jakarta: PT Bumi Aksara.

\section{Jurnal}

Jurnal Taswir, Kontribusi Lembaga Sufi Dalam Pendidikan Islam, Vol. 3 No. 5.

Jurnal Ilmu Syari'ah dan Hukum, 2011, Sahri, Dimensi Politik dalam AjaranAjaran Tasawuf: Studi Kasus atas Manaqib Syaikh Abd Al Qadir AlJailani, Asy Syir'ah: Vol. 45 No. II. 
